International Journal of Health Sciences
Available online at www.sciencescholar.us
Vol. 5 No. 3, December 2021, pages: 584-593
e-ISSN: 2550-696X, p-ISSN: 2550-6978
https://doi.org/10.53730/ijhs.v5n3.2540

\title{
The Educational Role in COVID-19 Terms of Ethnodesign Graphic Function in Higher Education Practical Activities
}

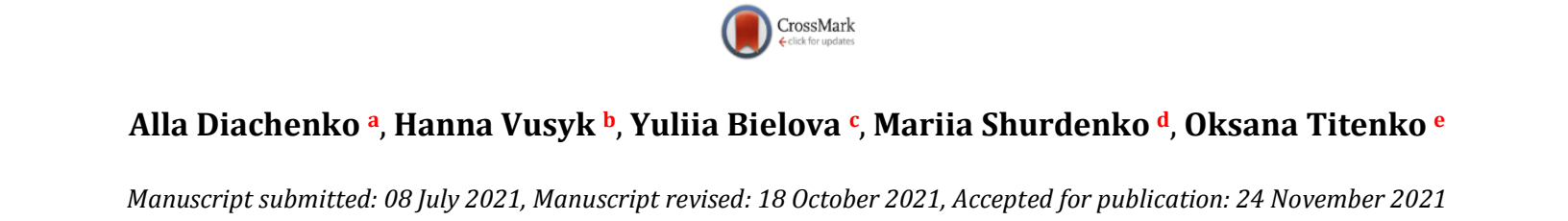

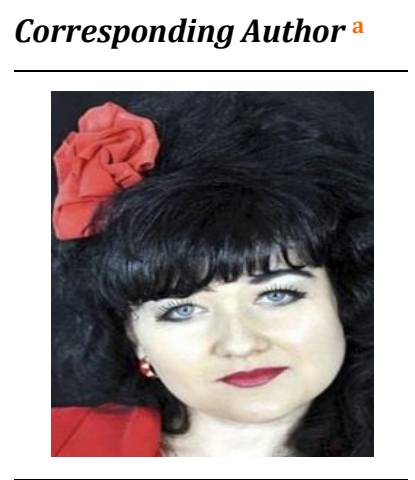

Keywords

COVID-19;

education;

educational impact;

educational model;

educational process;

educational program;

graphic design pedagogy;

university education;

\begin{abstract}
The research aims to establish the effectiveness and assessment of the educational role of graphic function of ethnodesign, as well as to determine the feasibility of using didactics outside the classroom practices in art education in the terms of COVID-19. The methodology of study is based on a qualitative approach designed to analyze the results of the research experiment, which provides for comprehensiveness in the study. The method of experiment in work is basic, also applied methods of interviewing and observation. The hypothesis is that in the development of art specialties curricula should be used extracurricular practical classes, where educational components of the graphic function of ethnodesign, as they form creative and educated professionals, actualize educational aspects. The result of the research is the establishment of positive assessment by the participants of educational process of using the graphic function of ethnodesign for educational purposes during practical extracurricular classes since this methodology contributes to the development of creativity and has significant innovative potential in revealing the creative abilities of art students, where students actively influence educational process together. The perspective in the research work is the further implementation of educational and training projects dedicated to the methods of teaching design courses.
\end{abstract}

International Journal of Health Sciences (C) 2021.

This is an open access article under the CC BY-NC-ND license (https://creativecommons.org/licenses/by-nc-nd/4.0/).

a Kyiv state Academy of decorative and applied arts and design named Mikhail Boychuka, Kyiv, Ukraine

b Berdyansk State Pedagogical University, Berdyansk, Ukraine

c Berdyansk State Pedagogical University, Berdyansk, Ukraine

d Berdyansk State Pedagogical University, Berdyansk, Ukraine

e Kyiv state Academy of decorative and applied arts and design named Mikhail Boychuka, Kyiv, Ukraine 


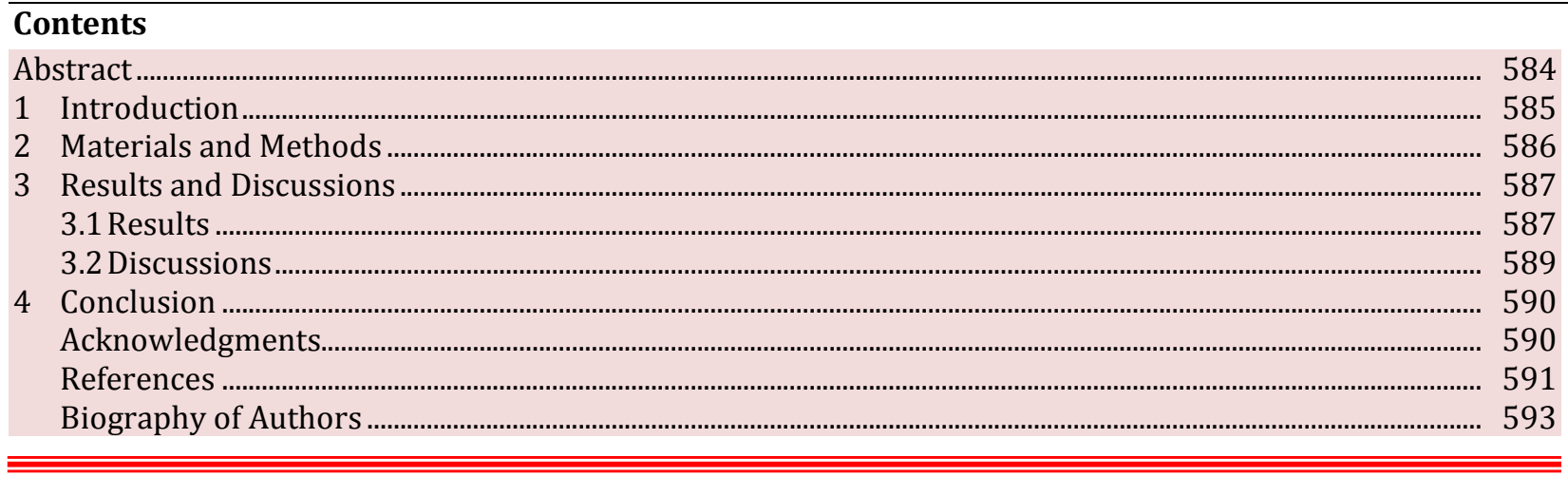

\section{Introduction}

An important and underutilized component of educational activities is extracurricular hands-on activities in the terms of COVID-19. A promising direction in the pedagogy of art education remains design, ethnodesign, graphic design function, which is part of quality university education (Townsend \& Armstrong 2017; Alhajr, 2016). The educational component in the structure of art education disciplines does not have a single developed concept, as well as a holistic vision of this process and its perception, and requires further development of the creative concept in contemporary art education, no exception to university education (Walker, 2017; Sadowska, 2018). In such a context, the development of a pedagogical component in the structure of design curricula remains relevant. It should increase creativity and help to realize the creative inclinations of applicants for education (Voinea, 2012).

Some studies consider the importance of creativity for the national art, traditional educational systems in general, which system is a part of the world educational process (Alhajr, 2016). Sometimes, for the development of design training courses, it is necessary to create unified creative concepts, to form innovative curricula, where artistic tasks would correlate with educational and training tasks. It makes relevant the research problem of finding the most convenient and open to the didactic activity of the teacher of academic disciplines and forms of work. It is what extracurricular practical work within ethnodesign can be. This is, first of all, the introduction of research experiments, the purpose of which is to determine the effectiveness of the systematic approach to teaching graphic design and the educational role of national cultures to help stimulate the creative potential of students (Dorst \& Cross, 2001). Consideration of the educational component in the implementation of courses on ethnodesign, its graphic components should be part of the work to improve the level of creativity, motivation for the profession, and the ability to appreciate cultural and national traditions today (Yates \& Twigg, 2017; Egan et al., 2017). It is promising in the modern pedagogy of art branch to consider the expediency of actualization of the educational role of design courses, teaching, and educational work in the conditions of extracurricular practical classes (Robinson \& Sexton, 1994).

This research aims at the effectiveness and evaluation of the educational role of ethnodesign graphic function in extracurricular practices in art education by applying several solutions: defining the stages in the process of creating an ethnodesign, a design project as an educational and educational model; establishing the nature of the difficulties encountered in the implementation of the educational role of the graphic function within the ethnodesign course; determining the evolution of the teacher's attitude to the implementation of the educational component in the practical lessons in the study of graphic topics in ethnodesign.

\section{Literature review}

A review of the literature on research on the pedagogical impact of graphic design in education (Davis, 2016; Ross, 2018), and studies specifically focus on the role of the transmission of reflective and educational practices in the teaching of graphic design (Cabianca, 2016; Bryan, 2005); the relevance and importance of this issue to contemporary university education. Unfortunately, there are few such studies. And this is not surprising, given the history of design research. The practice of teaching design has a long history, but it is

Diachenko, A., Vusyk, H., Bielova, Y., Shurdenko, M., \& Titenko, O. (2021). The educational role in COVID-19 terms of ethnodesign graphic function in higher education practical activities. International Journal of Health Sciences, 5(3), 584-593. https://doi.org/10.53730/ijhs.v5n3.2540 
younger than research in the mathematics and humanities. In the 1960s, an interest in the pedagogical characteristics of design-related disciplines led to the Design Research Society (DRS) creation. It also helped to make design studies not only a recognizable trend in pedagogy and teaching methods but also an important technique for designing the professional and creative development of society (Oxman, 2008).

Contemporary design studies consider a wide range of research problems: design thinking as creative thinking, the ability to experience the aesthetic needs of the audience (Braun, 2012; Kotamraju, 2002); the pedagogical component of learning through high technology and open learning tools in a postmodern education (Dzvinchuk at al., 2020; Čuhlová, 2019); implementation of design business projects in education from art to management (Jacobs, 2016; Grant, 2017); design as art education and a necessary third strand of the overall educational process (LaRossa, 2017; Widana et al., 2021); design pedagogy, which examines the problem of disciplining graphic design disciplines through the engagement of external practices, transparency, and mediation as catalysts for qualitative change (Littlejohn, 2017). The search for a harmonious combination of technological capabilities and creativity in design (Tan \& Melles, 2010; van der Waarde, 2020), where ethnodesign has a special place as a manifestation of folk identity, the continuation of cultural traditions, remains relevant to the problems to be considered.

\section{Materials and Methods}

The study of the influence on the education of future professional artists of the graphic function of ethnodesign as an artistic and applied discipline is based on integrated, systemic, and technological approaches. The integrated approach allows us to represent design techniques as the integration of teaching and educational methods, practices, the use of different forms of content, and artistic settings to present educational information and educational impact.

The systematic approach implies consideration of the educational role of ethnodesign as a system of actions, where the teacher's teaching and artistic experience and student's needs are primarily taken into account, components of the artistic personality are formed. Technological approach is obligatory when teaching design courses, it implies structuring the educational process as a sequence of pedagogical operations due to the logic of pedagogical work. Complexity in the research methodology allows organizing the educational process as a non-linear and multi-vector one.

The experiment was implemented during the academic year 2020-2021 for the students of the 1 group (22 people) of the National Pedagogical University named after Dragomanov M. P. (Ukraine), Faculty of History and Philosophy, specialty 022 Design. The experiment took place during out-of-classroom practical training for the study of pottery and ethnodesign based National Museum-Reserve of Ukrainian pottery in the Opishnia village (Poltava region, Ukraine). The research data were collected during the academic year 2020/2021 from teachers and students who worked and studied in the educational program in the specialty "Design". All teachers (4 people) who participated in the experiment are highly qualified specialists in ethnodesign, leading an active exhibition and production activities (Silakarma et al., 2021; Farooqui et al., 2018). All teachers have a $\mathrm{Ph}$.D. All teachers-respondents had from 10 to 24 years of experience in teaching in the graphic design and ethnodesign fields (Stones \& Cassidy, 2010). All of them were interested in conducting such an experiment and expressed a desire to improve their scientific and pedagogical skills. All teachers are members of the Union of Designers of Ukraine, frequent participants in creative competitions, exhibitions, projects are working on advanced training, and have diplomas in non-formal education (Kusumajaya, 2021). All study participants voluntarily agreed to participate in the research project. All respondents were guaranteed anonymity.

The research data were collected during the implementation of 3 stages of the research project. At the 1st stage (preparatory stage), preliminary interviewing of design teachers participating in the experiment was organized. Also, there were held consultations on participation in the research project, curricula, and were prepared materials for practical classes on the ethnodesign graphic function. The plan of art projects implementation and preparation of student works on ethnodesign was made. The didactic component of each academic topic is an obligatory part of the course.

At the second stage, teachers, and research, groups worked on practical extracurricular classes together with the students, created works and design projects, providing active use of materials for the course, which 
contained cognitive and educational components. At the final stage, a survey and interviewing of respondents were conducted, and the results were processed and analyzed. At the beginning and the end of the experiment, teachers were interviewed, and their evaluation of the introduction of the ethnodesign course was determined, taking into account the educational impact of the ethnodesign graphic function. Also, at the final stage, students and teachers were interviewed about their evaluation of the difficulties they encountered in studying the course.

\section{Results and Discussions}

\subsection{Results}

In general, the process of ethnodesign creating can be modeled through the establishment of certain stages. These are five stages, which in a general sense are defined as preparation, definition, material embodiment of the idea, transfer of the design produced.

Table 1

The stages of ethnodesign creation in the terms of COVID-19

\begin{tabular}{ll}
\hline Stage & Contents of the stage \\
\hline $\begin{array}{l}\text { Stage 1: preparation } \\
\text { (the gnoseological } \\
\text { aspect) }\end{array}$ & $\begin{array}{l}\text { Exploring the range of ideas with key activities. } \\
\text { Defining the expectations and needs of the target audience. } \\
\text { Analysis of market research, artistic trends and currents, and other sources of } \\
\text { information. }\end{array}$ \\
$\begin{array}{l}\text { Stage 2: } \\
\text { determination }\end{array}$ & $\begin{array}{l}\text { Searching for the best combination of ideas and directions, selected in the first } \\
\text { stage. } \\
\text { Analysis and synthesis into a brief concept, description of the key components of } \\
\text { the plan (project development, project management, project signing). }\end{array}$ \\
$\begin{array}{l}\text { Stage 3: } \\
\text { materialization of } \\
\text { the idea }\end{array}$ & $\begin{array}{l}\text { Creation of design solutions, variants of ethnodesign, their testing, using } \\
\text { interdisciplinary operational visualization, involving the method of creating } \\
\text { samples and prototypes. }\end{array}$ \\
$\begin{array}{l}\text { Stage 4: } \\
\text { implementation }\end{array}$ & $\begin{array}{l}\text { Final testing of ethnodesign product, making final variants, product evaluation, } \\
\text { building feedback loops. }\end{array}$ \\
Stage 5: reflection & $\begin{array}{l}\text { The opportunity to conclude, to describe the characteristics of the design process } \\
\text { and the technology of execution in the technique of graphic design. }\end{array}$ \\
\hline
\end{tabular}

Certainly, at each stage, it is necessary to use the educational potential that the graphic aspects of ethnodesign provide. Using the possibilities of ethnodesign involves teaching design processes, which involves integrative actions, providing flexibility of imagination and willingness to change, responding quickly to new things, maintaining creative trends, and especially the current fashion for the ethnic.

Diachenko, A., Vusyk, H., Bielova, Y., Shurdenko, M., \& Titenko, O. (2021). The educational role in COVID-19 terms of ethnodesign graphic function in higher education practical activities. International Journal of Health Sciences, 5(3), 584-593. https://doi.org/10.53730/ijhs.v5n3.2540 


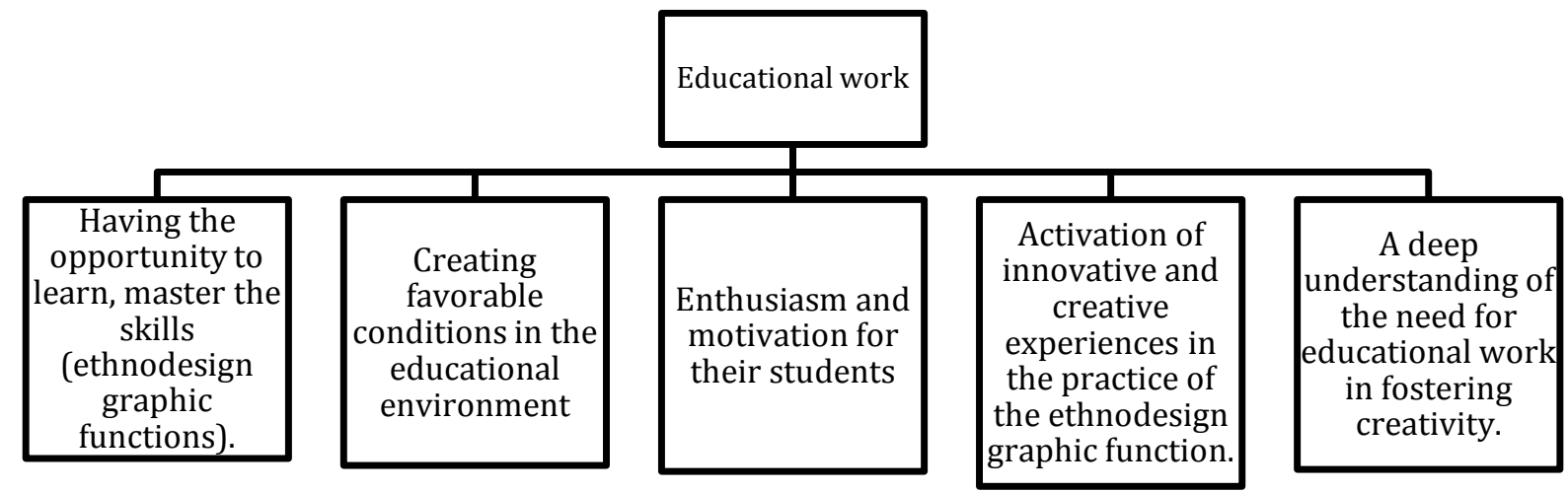

Figure 1. Conditions for the educational role implementation of ethnodesign creativity in the terms of COVID19 for the art majors

As we can see, in pedagogical science, it has long been known about the thesis that the individual creative process in education is an integral part of the overall educational process. Creating ideas and ways of their implementation, conventions, and development strategies, through which you can spread the idea, and artistic concepts, will be appreciated in the community, society, and the nation. And especially when it comes to ethnodesign, the system of its functions in the educational process.

Therefore, it can be argued that teachers are interested in activating the educational role of ethnodesign graphic function in university education. After that, the scientific and pedagogical staff and administration must ensure the availability of appropriate opportunities (extracurricular practice, exhibition activities, project activities). It is equally important to understand the value of fostering artistic attraction to creativity, the ability to interest and motivate their students in addressing innovative methods, the availability of experienced and methodological skills in teaching the graphic function of ethnodesign.

At the final stage of the project teachers and students were questioned about their evaluation of the difficulties of introducing and realizing the educational role of education, namely the graphic function within the ethnodesign curriculum for art majors. These are closed-ended questions that require "yes" or "no" answers; the answers are submitted as a percentage.

Table 2

The results of the survey on the difficulties of implementing the design component in the educational process at art majors in the terms of COVID-19

\begin{tabular}{|c|c|c|c|c|c|}
\hline \multirow{2}{*}{$\begin{array}{l}\text { № } \\
1\end{array}$} & Questions & \multicolumn{2}{|c|}{$\begin{array}{c}\text { Students } \\
\text { Yes } \\
\text { No }\end{array}$} & \multicolumn{2}{|c|}{$\begin{array}{c}\text { Teachers } \\
\text { Yes } \\
\text { No }\end{array}$} \\
\hline & $\begin{array}{l}\text { The lack of a sufficient level of creativity in the structure } \\
\text { of training programs. }\end{array}$ & 47 & 53 & 32 & 68 \\
\hline 2 & $\begin{array}{l}\text { Underestimation of the importance of the creative } \\
\text { component in university education. }\end{array}$ & 42 & 58 & 39 & 61 \\
\hline 3 & $\begin{array}{l}\text { The role of people's creativity in social and cultural } \\
\text { change is insufficient. }\end{array}$ & 16 & 84 & 42 & 58 \\
\hline 4 & $\begin{array}{l}\text { Lack of a unified vision of the educational role of the } \\
\text { design education course. }\end{array}$ & 12 & 88 & 80 & 20 \\
\hline 5 & Traditional educational system & 57 & 43 & 52 & 48 \\
\hline 6 & $\begin{array}{l}\text { Domestic graphic design education does not have a clear } \\
\text { strategy of "design creativity". }\end{array}$ & 14 & 86 & 10 & 90 \\
\hline 7 & $\begin{array}{l}\text { Lack of clear concept of the creative component of } \\
\text { educational work. }\end{array}$ & 36 & 64 & 51 & 49 \\
\hline
\end{tabular}


As a result of the respondent's assessment of the difficulties of implementing the educational component in teaching the practice of ethnodesign, it was determined that the greatest difficulties, according to students (57\%) and teachers (52\%), exist with the traditional and conservative educational system. It was also noted that there is not enough creativity in the structure of curricula. At the final stage of the project, the results of interviewing teachers and students who taught the academic discipline "Ethnodesign" and conducted extracurricular practical classes, and evaluated the results of the students' work, creative design projects. At the beginning and the end of the study, teachers were asked several questions about the feasibility of activating the educational component during extracurricular practical classes on ethnodesign; their answers are compared.

Table 3

The results of teachers' interviewing regarding their attitude towards the educational role of graphic ethnodesign in the terms of COVID-19

\begin{tabular}{|c|c|c|c|}
\hline Teacher & Question & Answer at the beginning & Answer at the final stage \\
\hline $\begin{array}{c}\text { Teacher } \\
1\end{array}$ & $\begin{array}{l}\text { How do you feel about the } \\
\text { teacher's educational work } \\
\text { when students explore the } \\
\text { graphic function of } \\
\text { ethnodesign? }\end{array}$ & $\begin{array}{l}\text { Positively. I give a few } \\
\text { educational materials as part of } \\
\text { the course, but no more due to } \\
\text { time constraints. }\end{array}$ & $\begin{array}{l}\text { It's a good practice. But I stand by } \\
\text { my point that I can allow a small } \\
\text { amount of educational material to } \\
\text { be given during out-of-adult } \\
\text { practice. }\end{array}$ \\
\hline $\begin{array}{c}\text { Teacher } \\
2\end{array}$ & $\begin{array}{l}\text { How do you feel about the } \\
\text { teacher's educational work } \\
\text { when students explore the } \\
\text { graphic function of } \\
\text { ethnodesign? }\end{array}$ & $\begin{array}{l}\text { Acceptable. Extracurricular } \\
\text { practice in ethnodesign is a } \\
\text { good way to carry out } \\
\text { educational work in the art } \\
\text { specialty. }\end{array}$ & $\begin{array}{l}\text { It is effective. We should continue } \\
\text { and develop this methodology, } \\
\text { increase the number of topics } \\
\text { with an educational element as } \\
\text { part of teaching ethnodesign. }\end{array}$ \\
\hline $\begin{array}{c}\text { Teacher } \\
3\end{array}$ & $\begin{array}{l}\text { How do you feel about the } \\
\text { teacher's educational work } \\
\text { when students explore the } \\
\text { graphic function of } \\
\text { ethnodesign? }\end{array}$ & $\begin{array}{l}\text { It is a useful experience. There } \\
\text { are } 2 \text { topics in the Ethnodesign } \\
\text { course that involve a significant } \\
\text { educational component. This is } \\
\text { always noted by students. }\end{array}$ & $\begin{array}{l}\text { I approve the practice, but I don't } \\
\text { think that much time should be } \\
\text { given to educational work only in } \\
\text { the process of teaching } \\
\text { ethnodesign. }\end{array}$ \\
\hline $\begin{array}{c}\text { Teacher } \\
4\end{array}$ & $\begin{array}{l}\text { How do you feel about the } \\
\text { teacher's educational work } \\
\text { when students explore the } \\
\text { graphic function of } \\
\text { ethnodesign? }\end{array}$ & $\begin{array}{l}\text { Good. I use animation at the } \\
\text { beginning and end of the school } \\
\text { year to give students a sense of } \\
\text { their progress. }\end{array}$ & $\begin{array}{l}\text { I enjoyed working that way. In } \\
\text { addition, mastering practical } \\
\text { skills and the ability to work on a } \\
\text { creative project in an out-of-the- } \\
\text { box setting, students were able to } \\
\text { recognize the responsible role of } \\
\text { the artist in society. }\end{array}$ \\
\hline
\end{tabular}

As we can see, 1 teacher out of 4 respondents was skeptical about the use of video to learn English grammar. One teacher considers it necessary to continue to actively use video content to learn the grammar of a foreign language. The rest were generally positive about this practice. In the beginning, the vision for the use of video content was vague and related more to forms of recreation and encouragement. At the end of the project, the vision of the purpose of using video in the study of grammar emerges an understanding of the need to introduce innovation in the educational process.

\subsection{Discussion}

The benefits of introducing the educational component in art education are considered in several works, where one of the main theses is the assertion of the need to nurture the creative potential of the artist and encourage students to understand design as a creative process. Alhajr (2016), during a study of the specifics of teaching the pedagogy of graphic design in Oman, noted that in traditional education, teachers prefer to

Diachenko, A., Vusyk, H., Bielova, Y., Shurdenko, M., \& Titenko, O. (2021). The educational role in COVID-19 terms of ethnodesign graphic function in higher education practical activities. International Journal of Health 
teach the understanding of the mechanisms of action of graphics, the technical skill of students, while the creative design thinking, the educational component remains outside the interests of teachers (Melles et al., 2012; Adams et al., 2011). In this study, this problem was noted by university art students and teachers. 57\% of students and teachers $52 \%$ pointed to the domination and resistance to traditional methods of education, preventing the realization of creativity to the fullest extent.

The issue of engaging innovative technology has also been addressed, and there have been successful results of implementing a system for teaching the graphic component of design using advanced digital technology (Cezzar, 2015; Owens \& Gibson, 2016; Salawali et al., 2021). Researchers have also pointed out that technical work opportunities alone, exceptional digitalization is not enough to educate not a craftsman but a true artist with an established artistic stance. Mastering design software doesn't make a professional designer. Creativity, a vision of artistic horizons, and the ability to form and implement ideas also can be part of an educational work that uses the graphic role of ethnodesign, innovative teaching methods (Meron, 2020; Taffe, 2017). Positive attitudes toward such practices have been shown by the evolution of teachers' opinions regarding the educational role of the graphic function of ethnodesign in practical extracurricular activities. In interdisciplinary fields of study, there is a growing interest in the influence of intuition, artistic talent, and creativity on the quality level of the artist's skill.

\section{Conclusion}

This research showed that ideational, creative, and technical skills are the components of a harmoniously formed artist's worldview, his/her mastership, and the ability to be creative. As a whole, the stage-by-stage model of the creation of ethnodesign consists of the following parts: preparatory stage (the gnoseological aspect of creativity); determination of priority, thematic and ideological bases of work; the material embodiment of the idea, ways, and forms of realization of artistic contents; the material realization of idea; display, delivery of finished work, project; the reflexion.

The role of interdisciplinary studies in contemporary art education is increasing, especially the important aspect of the "visual" within university education. The more important is a positive attitude to the educational role of design courses, scientific-technological research. The results of the research indicate that it is necessary to move away from purely traditional forms of university education (54.5\% of the respondents) and pay more attention to the innovative, creative components, which cherish the educational functions of activating creativity and intuition in art. It is necessary to expand the "language" of graphic ethnodesign, including the skills of analysis, reflection, intuitive perception of fashion, currents, ideas, etc.

The introduction of an educational component to graphic design instruction should instill the ability to carry out design practices focused on exploration and the communication of creative meanings. It can be useful for any project, inspiring designers to adopt a design process that is more responsive to the internal needs and desires of the audience and artistic experience in the terms of COVID-19.

Further, design thinking topics should be developed not only as technology but also as an artistic process, where the understanding of creative meanings, intuition, understanding of audience expectations, and knowledge of basic design trends rooted in national traditions are needed. Ethnodesign and its graphic role is not only a professional technical design as a special kind of technique but also an artistic tradition deeply rooted in cultural and national traditions in the terms of COVID-19.

Acknowledgments

We are grateful to two anonymous reviewers for their valuable comments on the earlier version of this paper. 


\section{References}

Adams, R. S., Daly, S. R., Mann, L. M., \& Dall'Alba, G. (2011). Being a professional: Three lenses into design thinking, acting, and being. Design Studies, 32(6), 588-607. https://doi.org/10.1016/j.destud.2011.07.004

Alhajri, S. (2016). The Effectiveness of Teaching Methods Used in Graphic Design Pedagogy in Both Analogue and Digital Education Systems. Universal Journal of Educational Research, 4(2), 422-425.

Braun, T. (2012). Dizayn-myshlenie: ot razrabotki novykh produktov do proektirovaniya biznes-modeley [Design Thinking: From New Product Development to Business Model Design]. Moskva: Mann, Ivanov i Ferber. Moskva: Izd-vo Mann, Ivanov i Ferber [in Russian].

Bryan, L. (2005). How Designers Think: the design process demystified.

Cabianca, D. (2016). A Case for the Sublime Uselessness of Graphic Design. Design and Culture, 8(1), 103-122.

Cezzar, J. (2015). What is graphic design. AIGA the professional association for design.

Čuhlová, R. (2019). Intercultural Adaptation Process and Its Determinants. International Journal of Economics, Finance and Management Sciences, 7(6), 215-221.

Davis, M. (2016). Tenure and design research: A disappointingly familiar discussion. Design and Culture, 8(1), 123-131.

Dorst, K., \& Cross, N. (2001). Creativity in the design process: co-evolution of problem-solution. Design studies, 22(5), 425-437. https://doi.org/10.1016/S0142-694X(01)00009-6

Dzvinchuk, D., Radchenko, O., Kachmar, O., Myskiv, I., \& Dolinska, N. (2020). Analysis of Platforms and Tools of Open Study in the Conditions of Postmodern Education. Revista Romaneasca pentru Educatie Multidimensionala, 12(3), 125-143.

Egan, A., Maguire, R., Christophers, L., \& Rooney, B. (2017). Developing creativity in higher education for 21st century learners: A protocol for a scoping review. International Journal of educational research, 82, 21-27. https://doi.org/10.1016/j.ijer.2016.12.004

Farooqui, N., Bansal, A., \& Agarwal, A. K. (2018). Impact of financial aid as scholarships on educational attainment \& quality of life among Muslim adolescent girls in madrasas. International Journal of Health \& Medical Sciences, 1(1), 1-9.

Grant, D. (2017). Special Business Degrees Mark Shift from Making Art to Managing It. The Chronicle of Higher Education.

Jacobs, J. (2016). Teaching the Business of Design Across Disciplines. The International Journal of Design Education, 10(2), 19-29.

Kotamraju, N. P. (2002). Keeping up: Web design skill and the reinvented worker. Information, Communication \& Society, 5(1), 1-26.

Kusumajaya, A. A. N. (2021). Individual and social environmental factor as risk factor of BMI-for-age in school children. International Journal of Health Sciences, 5(2), 89-98. https://doi.org/10.29332/ijhs.v5n2.1242

LaRossa, B. (2017). Design as a Third Area of General Education.

Littlejohn, D. (2017). Disciplining the graphic design discipline: The role of external engagement, mediating meaning, and transparency as catalysts for change. Art, Design \& Communication in Higher Education, 16(1), 33-51.

Melles, G., Howard, Z., \& Thompson-Whiteside, S. (2012). Teaching design thinking: Expanding horizons in design education. Procedia-Social and Behavioral Sciences, 31, 162-166. https://doi.org/10.1016/j.sbspro.2011.12.035

Meron, Y. (2020). Re-performing Design: Using dramaturgy to uncover graphic designers' perceptions of stakeholders. Exchanges: The Interdisciplinary Research Journal, 8(1), 71-90.

Owens, K. M., \& Gibson, M. R. (2016). It's time to stir the pot... Dialectic, 1(1), 5-8.

Oxman, R. (2008). Digital architecture as a challenge for design pedagogy: theory, knowledge, models and medium. Design studies, 29(2), 99-120. https://doi.org/10.1016/j.destud.2007.12.003

Robinson, P. B., \& Sexton, E. A. (1994). The effect of education and experience on self-employment success. Journal of business Venturing, 9(2), 141-156. https://doi.org/10.1016/0883-9026(94)90006-X

Ross, R. (2018). Producing Knowledge with Billboards: Graphic Design and Research. Design and Culture, 10(3), 299-321.

Sadowska, N., \& Laffy, D. (2018). Reframing boundaries of unfamiliar learning experiences through the use of design mock-ups in business management studies.

Diachenko, A., Vusyk, H., Bielova, Y., Shurdenko, M., \& Titenko, O. (2021). The educational role in COVID-19 terms of ethnodesign graphic function in higher education practical activities. International Journal of Health Sciences, 5(3), 584-593. https://doi.org/10.53730/ijhs.v5n3.2540 
Salawali, A. Q. ., Tahir, A. M. ., \& Hardjo, M. . (2021). The effect of family education on the fulfillment of family health tasks in handling case of hypertension post earthquake in Sigi regency. International Journal of Health \& Medical Sciences, 4(1), 136-140.

Silakarma, D., Adiputra, N., Sudewi, A. A. R., \& Widiana, I. G. R. (2021). Brain gym application and brain vitalization exercises in Balinese dance movement improves cognitive functions, quality of live and decreasing BDNF level in elderly. International Journal of Health Sciences, 5(2), 135-150. https://doi.org/10.29332/ijhs.v5n2.1356

Stones, C., \& Cassidy, T. (2010). Seeing and discovering: how do student designers reinterpret sketches and digital marks during graphic design ideation?. Design studies, 31(5), 439-460. https://doi.org/10.1016/j.destud.2010.05.003

Taffe, S. (2017). Who's in charge? End-users challenge graphic designers' intuition through visual verbal codesign. The Design Journal, 20(sup1), S390-S400.

Tan, S., \& Melles, G. (2010). An activity theory focused case study of graphic designers' tool-mediated activities during the conceptual design phase. Design studies, 31(5), 461-478. https://doi.org/10.1016/j.destud.2010.05.002

Townsend, S., \& Armstrong, H. (2017). Introduction: The Value of Design in an Academic Context. Design and Culture, 9(1), 67-68.

van der Waarde, K. (2020). Graphic design as visual arguments: does this make a reliable appraisal possible?. In Perspective on Design (pp. 89-101). Springer, Cham.

Voinea, M. (2012). The role of intercultural education in defining the system of individual values. ProcediaSocial and Behavioral Sciences, 33, 288-292. https://doi.org/10.1016/j.sbspro.2012.01.129

Walker, S. (2017). Research in graphic design. The Design Journal, 20(5), 549-559.

Widana, I.K., Sumetri, N.W., Sutapa, I.K., Suryasa, W. (2021). Anthropometric measures for better cardiovascular and musculoskeletal health. Computer Applications in Engineering Education, 29(3), 550561. https://doi.org/10.1002/cae.22202

Yates, E., \& Twigg, E. (2017). Developing creativity in early childhood studies students. Thinking Skills and Creativity, 23, 42-57. https://doi.org/10.1016/j.tsc.2016.11.001 


\section{Biography of Authors}

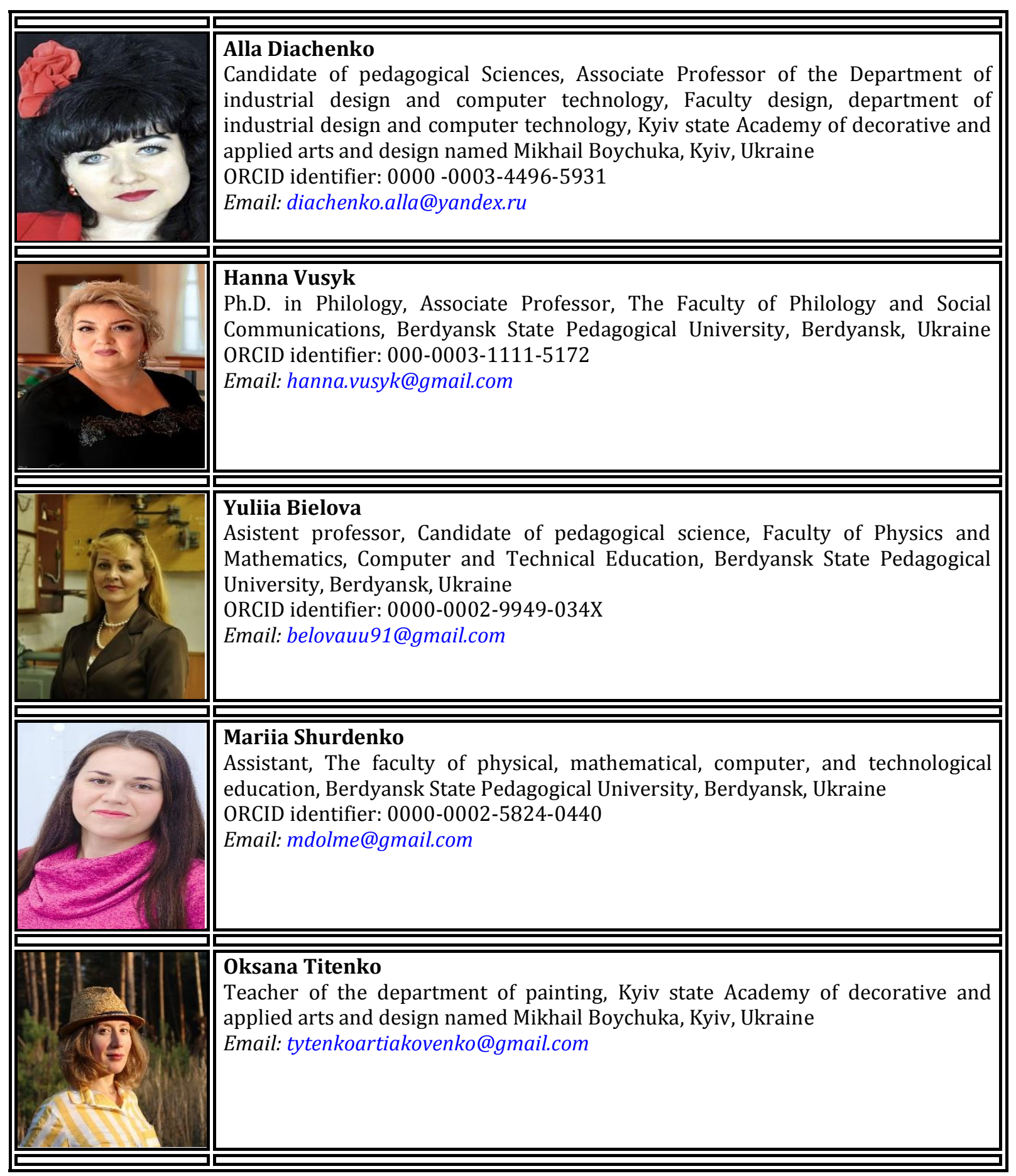

Diachenko, A., Vusyk, H., Bielova, Y., Shurdenko, M., \& Titenko, O. (2021). The educational role in COVID-19 terms of ethnodesign graphic function in higher education practical activities. International Journal of Health Sciences, 5(3), 584-593. https://doi.org/10.53730/ijhs.v5n3.2540 